\title{
ANATOMICAL CONSIDERATIONS IN INJECTION OF THE HIP JOINT
}

\author{
BY \\ J. M. F. LANDSMEER and A. K. J. KOUMANS \\ Laboratory of Anatomy and Embryology, University of Leyden, Netherlands
}

(RECEIVED FOR PUBLICATION MAY 24, 1954)

Recent developments in the treatment of affections of the hip joint by local injection of hydrocortisone, etc., require a safe and reliable route for injection. The methods described by Lanz and Wachsmuth (1938) comprise a lateral and a ventral approach to the joint. By the first method, the needle is pushed through the insertion of the gluteus medius muscle, the greater trochanter serving as the only landmark. The leg should be kept slightly adducted and the needle should pass right over the top of the greater trochanter in a horizontal direction, either in the frontal plane or with a slight dorsal deviation. By the second method, the needle is inserted over the femoral head and directed dorsally, and there are reliable landmarks to ensure correct positioning. By both methods the needle will enter the joint-space perpendicularly, so that only the point enters the actual cavity and the opening of the needle remains within the capsular layers. Such methods are only generally applicable in cases of exsudated joints, when the joint cavity has become filled with liquid and an exact approach is not necessary. An injection into an exsudated joint can be checked by the flowing out of the liquid, but in other cases there is no immediate response when the needle pierces the capsule. One must then be absolutely sure of the anatomical position of the needle.

Mawson (1946) described two methods of injecting joints in which there is no swelling:

(i) Anterior.-The needle is inserted midway between the great trochanter and the intersection of the femoral artery with Poupart's ligament; it is directed upwards, parallel with the femoral neck, inwards, and backwards.

(ii) Posterior.-The needle is inserted at a point just posterior to the great trochanter, and in an upward, inward, and forward direction.

This description seems to indicate that Mawson's approach to the joint cavity is tangential. The site of the needle is checked by injecting some fluid:

Once inside the joint the solution will run in easily. If much pressure is necessary the needle is probably outside the joint cavity embedded in the fibres of the capsule.

Hollander, Brown, Jessar, and Brown (1951), dealing with the intra-articular use of cortisone and hydrocortisone, do not describe their method of injection. Kron (1948) recognized the difficulties of an intra-articular injection into the hip.

Oest (1950), dealing with this problem, indicated the only reliable route for injecting into a non-distended hip joint, i.e. the caudo-lateral approach,? which ultimately leads the needle into the synovial sheath of the anterior aspect of the femoral neck. Oest guides the needle by means of metal threads, which have been stuck on the skin in the direction of the collum femoris. An $x$-ray photograph of the joint concerned shows the position of the femoral neck, and a second one taken after applying the metal threads serves as a control. This procedure is too laborious for routine use.

\section{Technique}

The method of injection should meet the following demands:

(a) it should be easy to perform so as to be practicable in general practice or in out-patient departments;

(b) the route of injection should be clear of large blood vessels or nerves;

(c) if possible, the injection should not be confined to a single narrow route, but should be practicable within a fairly large area.

We will take as a starting point a completed injection, where the top of the needle lies within the capsular extension along the neck of the femur. Running from a caudo-lateral direction, the needle 
will touch the caudal side of the femoral head the moment it reaches the intra-articular position. It should be noted that in the caudo-lateral approach to the capsule, apart from other advantages, the needle meets a check as soon as it has gained entrance into the capsule. Though it has been said to be possible to reach this space by guiding the needle in a ventrolateral-dorsomedial direction (Mawson, 1946), this route is difficult to trace through lack of reliable landmarks; apart from this the needle meets no resistance and may be run too far, possibly into one of the larger vessels.

In following the caudo-lateral route, the needle should perforate the skin at a point up to $5 \mathrm{~cm}$. caudal of the base of the greater trochanter. The point should be located in the plane of the ventral aspect of the femoral neck. Palpation of the greater trochanter gives sufficient guide to the site of injection; from this point the needle should run close to the ventral side of the femoral neck towards a point on the central third of a line from the ventral cranial iliac spine to the pubic tubercle (Fig. 1).

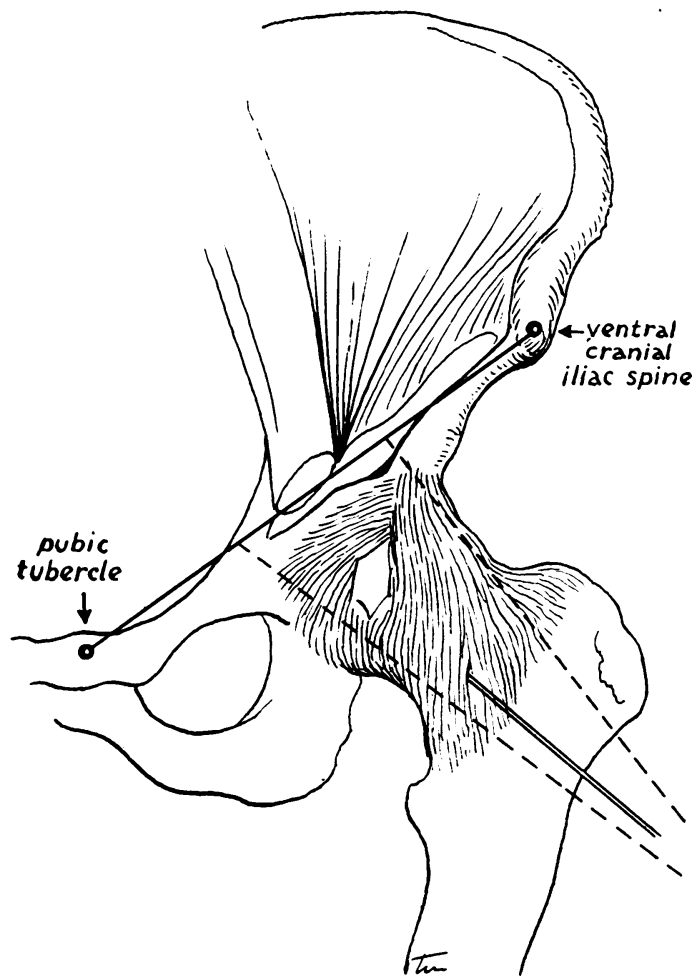

Fig. 1.-Drawing of a hip joint with the needle in the right position. Notice the site of perforation of the capsule and the direction of the route of injection in relation to the bony landmarks. The injection should take place within the dotted lines, which mark the "area of safety'.'
This allows for an arc of deviation of $10-20^{\circ}$. There is not merely one possible route, and it does not matter where precisely the needle gains entrance to the ventral capsular pocket, as long as it keeps its caudo-lateral, cranio-medial direction. Therefore a considerable latitude is allowed in performing this injection. Our data may be regarded as defining safe limits for a successful result, but it is absolutely necessary to go right over the ventral surface of the femoral neck.

Carrying out the injection on an intact preparation or on a patient, the needle will meet some typical resistances. After perforation of the skin, the first resistance is offered by the fascia lata. The needle will pass through the muscular tissue unhampered, to meet further resistance in the joint capsule. Having passed this barrier, as soon as it touches the bone, the needle's whole aperture will be within the joint cavity (Fig. 2). There is one other potential obstacle, viz. the intertrochanteric line; it will be recognizable at once by its short distance from the skin and by the fact that the needle will meet it

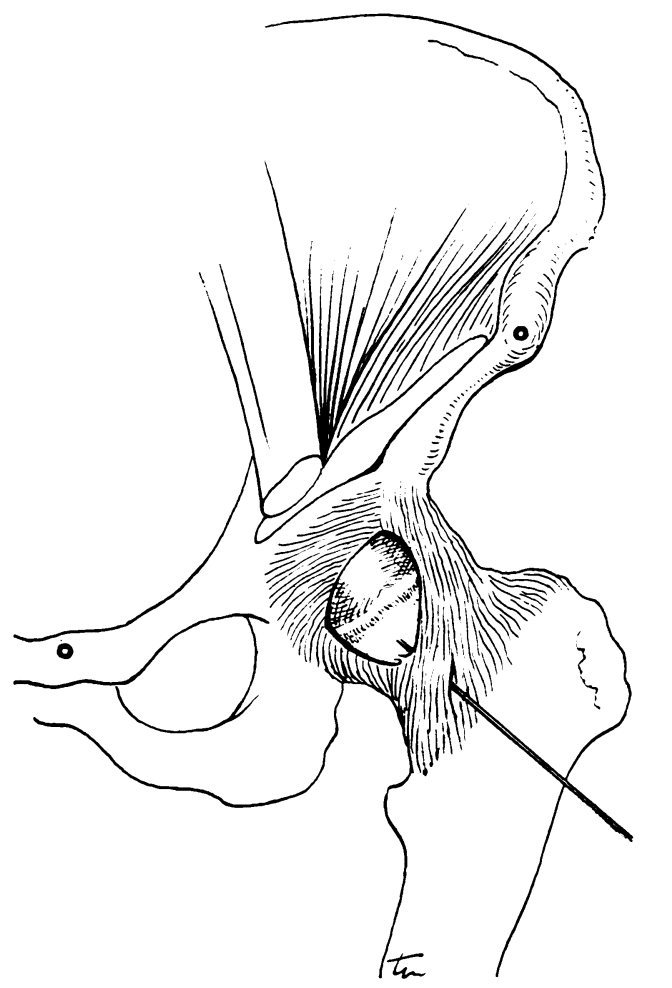

Fig. 2.-The capsule has been opened so as to show the position of the injection canal in relation to the femoral neck and synovial outpocketing at its ventral side. Both drawings are from a specimen injected with plastic material and then arranged as a joint preparation. 
before passing the second "resistance". Should this occur, the needle should be withdrawn for a short distance, and then directed slightly ventrally of the first route.

We practised this injection on a great many cadaver subjects and found it always possible to run the needle into the joint cavity without difficulty.

\section{Verification of Position}

There is no real need to check the injection by other means than those already mentioned. If the needle is directed by means of the anatomical landmarks described above it cannot fail to enter the capsule. However, though it is not necessary to verify the position of the needle, its intra-articular position may be shown by various methods. The injection of an opaque material such as Ba-sulphate will show the site of injection on an $x$-ray film, since an intra-articular deposit of fluid will spread along and around the femoral neck. This method is applicable only to cadaver material. A fluid plastic substance may be injected into a cadaver joint cavity, and the injection may be continued while withdrawing the needle. After polymerizing the plastic substance the route of injection-a plastic thread-can be demonstrated in continuity with the joint cavity, and a plastic cast of the joint space may be made (Figs 1 and 2).

\section{Injection}

Finally, it is possible to inject a large quantity of fluid or air into the joint cavity, after which an increase of intracapsular tension will occur. When the piston-bar of the syringe is released, the fluid or air will run back into the syringe. We applied this method quite often to demonstrate the site of the tip of the needle. One of us tried this intervention on an apparently normal hip joint and found the liquid (a physiological salt solution) flowed back into the syringe. This phenomenon would not be seen in normal peri-articular tissue, for in normal tissue the liquid, when injected peri-articularly, spreads into the tissue spaces, and is not collected in one cavity. In pathological tissues one should be prepared to meet other reactions. Our observations seem to indicate that in certain circumstances, peri-articularly deposited fluid may flow back into the syringe. The tissue spaces seem to be occluded, by which procedure thick connective tissue plates will develop. This pathological tissue (HartspannMüller, "Myogelosen" Schade) does not absorb the fluid like a sponge, but opposes a fluid injection. Apparently the fluid collects, and is soon under high tension, so that releasing the piston-bar allows it to flow back into the syringe. Evaluation of the reflow of fluid in pathological cases should therefore be made carefully and with much reserve.

By appropriate handling of the needle failures may be entirely excluded. The touch of the needle against the caudal aspect of the femoral head provides instant proof of its position.

The method is easy to practise, there are no vulnerable arteries or nerves on its route, and the needle is guided by landmarks, a definite stop being formed by the femoral head itself.

We have found it almost impossible to penetrate the capsule on its lateral side, and we were not able in our cadaver experiments to inject air or liquid into the joint cavity by this route. It remains possible to reach and penetrate the capsule in its ventral aspect, approaching laterally from above. This method has notable disadvantages, since tracing is difficult and the needle meets no resistance the moment it pierces the capsule.

In our opinion this caudo-lateral approach in the direction of the femoral head, going close to the ventral aspect of the femur, should be chosen without reserve for all injections into non-distended hip joints.

\section{Summary}

The injection of a hip joint not containing a fluid reservoir presents various difficulties. For anatom ical reasons the joint should be approached from the? caudo-lateral side. The needle should be inserted at a point up to $5 \mathrm{~cm}$. caudal of the base of the greater trochanter and should be directed to a point on the middle third of a line between the iliac spine and the pubic tubercle. The needle should run right over the ventral surface of the femoral neck. As soon as the needle touches a bony resistance-the caudal aspect of the femoral head-its aperture is within the joint space.

\section{REFERENCES}

Hollander, J. L., Brown, E. M., Jessar, R. A., and Brown, C. Y. (1951). J. Amer. med. Ass., 147, 1629.

Kron, R. (1948). Schweiz. med. Wschr., 78, 80.

Lanz, T. von, and Wachsmuth, W. (1938). "Praktische Anatomie", vol. 1, chap. 4, p. 173. Springer, Berlin.

Mawson, R. (1946). Brit. med. J., 2, 691.

Mawson, ${ }_{\text {O. (1950). Z. Orthop., 79, } 154 \text {. }}$

\section{Consíderation anatomique de l'injection coxo-fémorale}

\section{RÉSUMÉ}

L'injection de l'articulation coxo-fémorale amène des difficultés en cas où la capsule n'est pas distendue par une exsudation. Puisqu'il n'y a pas de réponse immédiate en perforant la capsule, il faut se confier entièrement aux points de repère anatomiques. L'aiguille doit être introduite à un point situé jusqu'à $5 \mathrm{~cm}$. en-dessous du grand trochanter en direction médiocraniale, notamment vers un point du tiers moyen de la ligne épine iliaque antéro-supérieure-épine du pubis. 
L'aiguille, cheminant au ras de la face ventrale du col du fémur, se heurtera contra la face inférieure de la tête. A ce moment l'aperture de l'aiguille aura une position intra-articulaire, à savoir dans le cul de sac capsulaire de la face ventrale du col du fémur.

Consideraciones anatómicas sobre inyecciones en la articulación de la cadera

$$
\text { SUMERIo }
$$

Una inyección en la articulación de la cadera que no contiene líquido presenta varias dificuldades. Por razones anatómicas habrá que acostarla caudo-lateralmente. Se inserta la aguja á $5 \mathrm{~cm}$. debajo del gran trocanter en el sentido caudal y se la dirige hacia un punto situado sobre la media tercera parte de la línea entre la espina iliaca y la tuberosidad púbica. La aguja debe pasar directamente sobre la superficie ventral del femur. Al sentir con la aguja una resistancia óseael aspecto caudal de la cabeza femoral-se sabe que la punta está en el espacio articular. 